\title{
FACTORS AFFECTING THE USE OF E-MONEY (STUDY ON E-MONEY USER IN CITY OF SOUTH TANGERANG)
}

\author{
Dian Widiyati ${ }^{1}$, Neneng Hasanah ${ }^{2}$ \\ ${ }^{1,2}$ Akuntansi S1, Ekonomi, Pamulang University, Jl. Surya Kencana No. 1, Tangerang Selatan, 15412, Indonesia \\ ${ }^{1}$ Corresponding e-mail: dosen02421@unpam.ac.id
}

\begin{abstract}
The purpose of this study is to analyze the factors that influence the use of e-money. The type of study is a quantitative method questionnaires distributed in soft copy (Google Form). The samples included 107 people who lived in the city of South Tangerang, Banten. Samples are taken by simple random sampling technique. The analytical method used is the analysis of multiple data processing using E-Views 8. The results of this experiment show that the variables of Perceived Benefit and Compatibility does not affect the use of e-money, while Perceived Usefulness variables influence the use of e-money and also, Perceived of Benefit, Compatibility and Perceived Usefulness affect on the use of e-money together.
\end{abstract}

Keywords: perceived benefit; compatibility; perceived usefullness; e-money

JEL Classification : G40, G41, O35

\section{Article info:}

Received 22 June 2020

Revised 30 June 2020

Accepted 30 June 2020

Available online 1 July 2020

\section{INTRODUCTION}

The rapid technological development in the digital era is now successfully changing the pattern of life and payment systems of economic transactions in society. As computers evolved and internet access expanded, the creation of more efficient payment service systems became increasingly possible. Along with changing times and technological developments, paper money transactions (cash) are no longer effective and many are using e-money. Especially in cities, the use of electronic money (e-money) is quite high. The city of South Tangerang for example is a town in Province of Banten which has high enough money circulation. In southern Tangerang, the use of e-money has increased from year to year. The government of city of South Tangerang supports e-money by launching the Tangsel Pay. Ease of paying taxes and retribution in South Tangerang area using the Tangsel Pay application.

Transactions using electronic cash unspecified minimum number of transactions that is relatively small. In addition, because no security verification process (either by PIN or signature), the e-money transactions is relatively quickly (Wulandari et al., 2016). The increasing number for users of e-money mostly caused by currency as physical form that often used in every transaction has many weaknesses, namely: First, currency is less practical. Cash transactions will run inefficiently because the buyer must carry a currency equal to the price of the item and it is considered impractical. Second, the seller will be inconvenienced to provide change so they will ignore the buyer's right to get change and give the change only with goods that are approximately the same price (Adityawarman, 2014). In addition, the management and printing costs of currency are very large, the use of currency is less practical because of the long queues at the cashier because very few buyers prepare 
money for the purchase price or transaction value to be paid. The weakness of currency can be falsified, so that it can harm other people who transact and then get counterfeit money.

The Central Bank of Indonesia announces that use of cash has constraints in terms of efficiency, it is due to procurement and management (cash handling), time efficiency, and security risks (Bank Indonesia, 2011). Therefore, the Central Bank of Indonesia issues Less Cash Society policy issued in period 2005-2006 (Siaran Pers Bank Indonesia, 2016). This policy aims to reduce the use of cash instruments that have long been applied to public transaction activities. E-money is money that can be transferred electronically from the buyer to the seller (Popovska-Kamnar, 2014). The purpose of e-money is as a means of payment that can provide benefits in the form of providing convenience and speed in making payment transactions without the need to carry cash. The use of e-money is different from credit and debit cards which must be connected to a customer's bank account. However, e-money has a different system, namely the prepaid system.

Ease, speed, and efficiency are the motivations of users to use e-money. At present, an online system at a bank is an effective method because it offers many benefits compared to the offline system. Therefore the banking industry is trying to continue to offer useful benefits to consumers (for example, giving bonuses or gifts, ease and speed of transactions) so as to increase the use of online banking (Lee, 2009). Perceived benefit is a factor that influences consumers to use e-money in Indonesia. In other words, consumers in Indonesia adopt e-money if they feel that e-money makes their activities easier, saves time, provides discounts or promotions, is more efficient than using cash, debit/credit cards, easy to find topup places, and can be used anywhere (Miliani et al., 2013). According to Hoffmann (2011), compatibility is the extent to which an innovation is considered consistent with existing values, past experience, and consumer needs. The higher the compatibility the more confident consumers are adopting the technology. According to Oliveira et al. (2016), consumers consider mobile payment to be compatible if they feel the benefits of the application to carry out an activity, so compatibility can strengthen the intention to use a technology.

Individual interest in using e-money can be measured using a theory that can describe the level of acceptance and use of a technology. In this study the acceptance theory used is the Technology Acceptance Model (TAM) theory which developed by Davis (1989). In the TAM concept, Davis (1989) defines that perceived usefulness as a belief in usefulness which is the degree to which users believe that the use of technology/system will improve their performance at work. Perceived usefulness is defined as the extent to which a person believes that the use of a particular information system will improve its performance. On this definition, it is known that the perception of usefulness is a belief about the decision making process. In the other hand, according to Anjelina (2018), perceived usefulness, perceived ease of use, compatibility, perceived trust, perceived risk, and perceived cost statistically are not factors that determine someone to adopt e-money in Indonesia.

\section{LITERATURE REVIEWS}

\subsection{Technology Acceptance Model}

The Technology Acceptance Model (TAM) was first developed by Davis (1989), another TAM modification is Trust and Risk in Technology Acceptance Model (TRITAM) that uses trust and variables joint risk TAM variable (Lui and Jamieson, 2003). Technology Acceptance Model (TAM) developed by Davis (1989) is a successful and very acceptable model to predict acceptance of a newly applied technology. Recently, TAM is one of the most important theoretical contributions to acceptance and the use of an information system. Many studies have re-examined, expanded, and using TAM. The TAM model is actually adopted from the TRA model, namely action theory which reasoned with one premise that one's reaction and perception of something, will determine the person's attitude and behavior. 
Reactions and perceptions of users of Information Technology (IT) will influence its attitude in acceptance of the technology. One factor that can influence it is the user's perception of the usefulness and ease of use of IT as an action within reasoned the context of the user of technology, so that the reason someone sees the benefits and ease of use of IT makes the actions/behavior of the person as a benchmark in acceptance of a technology. According to Davis (1989), the behavior of using IT begins by there is a perception of the benefits (perceived of usefulness) and perceptions about the ease of using information technology (ease of use). Both of these components when associated with TRA is part of belief. Davis (1989) defines perception of usefulness (perceived of usefulness) is based on the definition of the word useful that is capable of being used advantageously, or can be used for beneficial purposes. Perception of usability is the benefit that an individual believes he can obtain when using information technology. Potential users believe that certain applications are useful, maybe they, at the same time, believe that this system is too difficult to use and the benefits derived from using it outweigh the attempts to use the application. That is, on the side the benefits or uses, the application of information technology systems will also be influenced by perceived ease of use (perceived ease of use). Therefore Davis (1989) adds two components to the TAM model. So, according to Davis (1989), there are five the formation of attitudes that affect one's behavior in the use of technology information:

1. Perceived Ease of Use for ensuring that information technology will be easy to use.

2. Perceived Usefulness to ensure that the information technology used will be provide benefits.

3. Atitude Toward Using for convincing the user's attitude to use technology Information.

4. Behavioral Intention of Use to improve user behavior to continue using information technology.

5. Actual System Usage where user has fully used information technology based on the benefits obtained.

\subsection{Mobile Payment}

Mobile payment is receiving growing attention globally from consumers to merchants as an alternative to using cash, check, or credit cards. The potential of this technology is enormous (Oliveira et al., 2016). Mobile Payment or abbreviated as M-Payment is a method of payment that uses a mobile phone or cellphone as a means. Mobile Payment which is widely known by mobile users is certainly a banking product called Mobile Banking or abbreviated as M-Banking. Through M-Banking services, we can check the balance of our savings accounts at the Bank, transfer money, pay bills, including the purchase of top up pulses. In using Mobile Payment or M-Banking, each bank has a different menu and method, some use a menu derived from our cellphone Sim Card (provided by a cellular operator called the SIM Toolkit menu), some use a Java application that can be clicked on from our mobile menu, and some use SMS codes and send to certain numbers (SMS Banking). This method is very practical as an alternative to transactions through ATM machines or tellers at the Bank's branch offices. In addition to M-Banking, which is generally managed by a banking system, Bank Indonesia has allowed cellular operators to operate a card payment system, specifically for micro payments. This system is referred to as Electronic Wallet (EWallet) or for mobile phones also called MobileWallet (abbreviated as M-Wallet). GSM cellular operators that already have this kind of service are Indosat under the name Dompetku and Telkomsel with Tcash, while XL is in the process and the plan will be called XL Cash. Besides that, there is also $\mathrm{M}$ Wallet from Flexi which is then managed by another Telkom subsidiary, Finnet called M cash. Initially, the technology used in M-Wallet was based on SMS technology, but at present Telkomsel and Tcash are planning Flash (RFID or Wireless) technology-based products, namely contactless technology such as those used in Flash BCA and Mandiri eToll. By this technology, all transactions become easier because we just need to 
attach our cellphones to make transactions and pulsakita (credit wallet) will be debited automatically at the transaction value that we do. The payment system is an important component in the economy especially to ensure the implementation of payment transactions made by the public and the business world. In addition, the payment system also plays an important role in supporting financial system stability and implementation of monetary policy (Lintangsari et al., 2018).

\subsection{Electronic Wallet}

According to the Regulation of Central Bank of Indonesia Number 18/40/PBI/2016 Article 1 no 7 defines that Electronic Wallet, hereinafter referred to as Electronic Wallet is a service electronic data to store payment instruments, among others, means of payment with use cards and/or electronic money, which can also hold funds, for make a payment. E-wallet or electronic wallet is an application or feature developed to facilitate users in making payments. E-wallets have become a trend after many start-up companies developing business based on online transactions have sprung up in Indonesia. The system of e-wallet itself is, you put a certain amount of money into your e-wallet account. Later this money can be directly used for shopping at merchants who have collaborated with the e-wallet developer. E-wallet users are also increasingly tempted to use this facility because there are many promos offered from e-wallet applications. Ranging from discounts to points that can be exchanged for free services or products. Therefore, e-wallet users feel they have nothing to lose using this facility for shopping. One of the most felt advantages of e-wallet is that it offers high ease and flexibility. To use this digital wallet, we only need to install the e-wallet application on the smartphone. By this, we no longer need to carry a thick wallet full of cash, debit/credit cards, or queue to make cash withdrawals at ATMs. In addition, e-wallet is also safer and easier to carry when traveling. Another advantage of this e-wallet is the existence of a transaction history that makes it easy for us in financial records. We can easily find the transaction history that you want to search and store securely in digital form. Transaction information recorded is also more detailed and arranged in such a way that it looks neat and clear. Various promotions presented by digital payment services will benefit users. Promotions such as cash back or discounts become one of the things that attract users to use the service. Based on JakPat research on 1,625 respondents in October 2018, as many as 65\% of respondents use digital payments when there is a promotion program. Meanwhile, other respondents will use digital payment services when: do not carry money or credit/debit cards or about $60.2 \%$, almost every time or about $42.7 \%$, and feel non-cash transactions are better than cash or about 24.5\% (Warta Ekonomi, 2019). Offer on programs like Pay Day from GoPay felt by digital wallet users. There are also those who give reward points as well additional free products, such as T-Cash. That can help improve your cash flow marginally. If it's stolen, we can block e-wallets through connected accounts on mobile devices. That way, the money in the digital wallet might not be used anymore. E-wallet services in Indonesia are also adjusted to the regulations of the regulator. In line with regulation of Central Bank of Indonesia, the digital payment provider application system such as Dana is integrated with Dukcapil's data to carry out the KYC process. Through the integrated data, fund registration can be done using citizenship card (or called Kartu Tanda Penduduk) and family register card (or called Kartu Keluarga). While the weakness of e-wallet is that the service is still limited, although it offers many conveniences, e-wallet service is still limited. This e-wallet can only be used for merchants who have collaborated with the e-wallet issuer itself and does not offer returns, digital wallet is not same as a bank account where if more and more of our money is deposited there is no interest at all. The advantages of e-wallet do not burden administrative costs that can reduce the balance of our wallet. This means that our money in e-wallets will not grow. According to Saraswati and Mukhlis (2018), the non-cash payments can improve 
efficiency, effectiveness and financial productivity which are expected to increase economic activity in Indonesia, which will promote economic growth and community welfare.

\section{RESEARCH METHOD}

\subsection{Data}

This research is an associative research intended to determine the relationship between two or more variables, and in this case the relationship is causal in which the independent variable influences the dependent variable. To get the data needed in this study, the type of data used is primary data. According to Narimawati (2008) in Yulianto et al. (2016), primary data is data that originated from the original or first source, this data is not available in compiled form or in the form of files. According to Sugiyono (2014:193), primary sources are data sources that directly provide data to data collectors. This data must be sought through sources or respondents, namely the people we make the object of research or the people we make as a means of getting information or data. Primary data sources in this study are data collected based on the results of filling in a list of questions that have been prepared in advance. Data obtained by distributing questionnaire questions directly to the public through Google Form. The questionnaire filler community has at least one e-Money electronic money product and has conducted transactions with e-Money. The type of questionnaire that used is a closed questionnaire that is a questionnaire that has provided the answer, the reason the authors use a closed questionnaire because this questionnaire makes it easy for respondents to provide answers, closed questionnaires are more practical and can compensate for limited costs and research time. The questionnaire in this study adopted the research questionnaire from Ma'ruf (2016).

\subsection{Sample}

In this study the population used is the people of the city of South Tangerang who have at least 1 (one) e-Money electronic money and have conducted transactions using emoney electronic money. In this study, sampling using simple random sampling technique. Simple random sampling is taking sample members from a population done randomly without regard to strata that exist in that population. The total sample in this study is 107 of emoney users.

\subsection{Method of analysis}

The analytical tool used in this study is multiple linear regression analysis using EViews 8. According to Sekaran (2003:42), validity tests how well an instrument is made measuring certain concepts that you want to measure. This validity test can be done by calculating the correlation between each statement with a total score using the product moment correlation formula. There are several tests that must be run first, before a correlation and regression analysis is made, this is to test whether the model used represents or approaches existing reality. To test the feasibility of the regression model used, it must first meet the classical assumption test.

a. The normality test aims to test whether in the regression model the independent variable, the dependent variable or both have normal distribution or not. In the E-Views program, normality testing is done with the Jarque-Bera test. The Jarque-Bera Test has a Chi-Square value of two degrees of freedom. If the Jarque-Bera test results are greater than the ChiSquare value at $\alpha=5 \%$, then the null hypothesis is accepted which means the data is normally distributed. If the Jarque-Bera test results are smaller than the Chi-Square value at $\alpha=5 \%$, then the null hypothesis is rejected which means it is not normally distributed.

b. Multicollinearity test aims to test whether the regression model found a correlation between independent variables. To detect multicollinearity, it can be done by looking at the value of Tolerance and Variance Inflation Factor (VIF) and the magnitude of correlation between independent variables. 
c. Heteroscedasticity test is a violation of the assumptions in the multiple regression equation where the variance of each error of the independent variable is not constant over time. Heteroscedasticity causes the estimation results with OLS will produce parameters that are biased, inefficient or consistent, meaning that the coefficient produced is not from the smallest error variant. In the E-Views program, a test to see if there is heterokedasticity in an equation is to use the White-test.

d. Correlation analysis is an analysis technique that is included in one of the association / relationship measurement techniques. Association measurement is a general term that refers to a group of techniques in bivariate statistics used in a group of techniques in bivariate statistics used to measure the strength of the relationship between two variables, whereas in multiple regression analysis, estimation of model parameters with panel data, using several techniques, namely:

1) Common Effect Model (Ordinary Least Square). This model is the simplest model. In the estimation it is assumed that each individual thread has the same intercept and slope (there is no difference in the strict dimension of time). In other words, the resulting panel data regression will apply to each individual.

2) The Fixed Effect Model. The fixed effect model is a panel data regression model obtained by assuming that the cross section units and time series used in the model are known in advance, the MET in this study has a constant variation in the cross section unit and the coefficient of the constant assumes that the difference in influence from the unit cross section and time series are reflected by different constants.

3) The Random Effect Model. This model is also called the component error model. Just like the fixed effects model, this model also allows for differences in the values of intercept parameters and coefficients differing between regions and between times, which are expressed in errors. In this model the disturbance is assumed to be random for the entire population. This model assumes that individual errors do not correlate with each other, nor do the combination errors. By using this model, we can save the use of degrees of freedom and not reduce the amount as in the fixed effect model. This has implications for the parameter estimation results will be efficient.

e. The coefficient of determination is used to test the extent to which the variation of the dependent variable can be explained by the independent variable. The value of $\mathrm{R} 2$ is a fraction of the variation that can be explained by the independent variable to the dependent variable. The value of $\mathrm{R} 2$ ranges from $0-1$ percent and if the value approaches 1 then the better of R2.

\section{RESULTS AND DISCUSSIONS}

\subsection{Results}

This study uses multiple regression analysis. The theoretical model described in the previous path diagram will do the analysis based on the data that has been obtained. The final sample size in this study is 107 respondents. The questionnaire measured using a Likert scale with a range of 1 (Strongly Disagree), 2 (Disagree), 3 (Less Agree), 4 (Somewhat Agree), 5 (Agree), and 6 (Strongly Agree). Data analysis is performed with some procedures, where the first is to analyze the validity. Both analyzed with multiple regression analysis using E-Views version 8. The personal characteristics of respondents can be seen in Figure 1. 
Age

107 responses

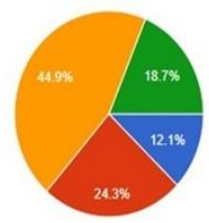

University

107 responses

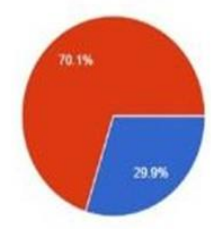

Gender

107 responses

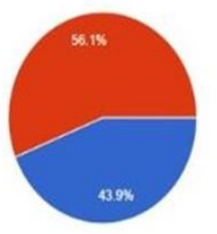

- Male

- 20 years old
$20-25$ years old

$26-30$ years old

$>30$ years old

$>30$ yearsold

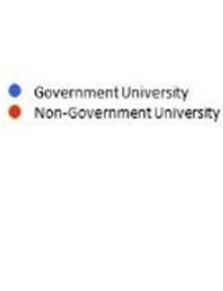

Education

107 responses

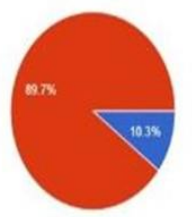
- Senicatigh School

Figure 1. Characteristics of respondents

Validity test - Samples obtained in this study are 107 respondents with the degrees of freedom (degree of freedom) is $\mathrm{n}-2=105$. Values $\mathrm{r}$ table with degrees of freedom $(\mathrm{df})=105$ at 0.05 Alpha acquired 0.1900 . On output obtained, all valid questions because the correlation value is greater than 0.1900 . The validity of the results can be seen in the attachment. Based on Figure 2, the normality test results shows that the value of the Jarque-Bera of $36.71123 \mathrm{p}$ value of 0.0000 or less than 0.05 which means that distribution data is not normal.

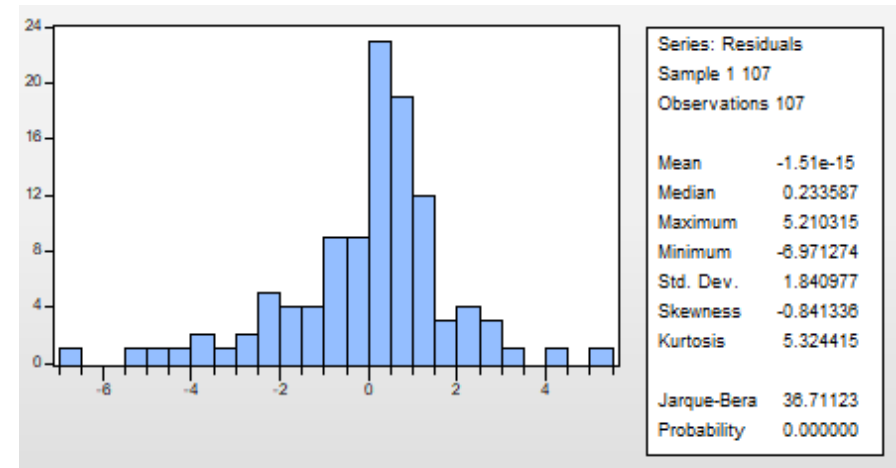

Figure 2. Normality test

Table 1 shows the result of heteroscedasticity test results show the value of Prob. Chi-Square (3) in Obs * R-Squared is equal to 0.0196 where $<0.05$ then the regression model is homoscedasticity.

Table 1. Result of heteroscedasticity Test 
Table 2 shows that based on multicollinearity test then all correlation values are less than 10 , then it can be concluded that there are no problem of multicollinearity in the model predictions.

Tabel 2. Result of Multicollinearity Test

\begin{tabular}{lc}
\hline Variable & Variance Inflation Factor (VIF) \\
\hline PBN & 9.3742 \\
CPB & 4.6354 \\
PUF & 6.5576 \\
\hline
\end{tabular}

Note: PBN is Perceived of Benefit, CPB is Compatibility and PUF is Perceived Usefulness

Table 3 shows the autocorrelation test based on the $\mathrm{p}$ value of Breusch test-Godfrey Serial Correlation LM where the value is equal to 0.2518 and it is more than 0.05 which means that there is no problem of autocorrelation.

Table 3. Result of autocorrelation Test

Obs*R-Squared $\quad$ Prob. Chi-Square

$2.757895 \quad 0,2518$

\subsection{Discussions}

Based on Table 4, the variable Perceived of Benefit shows that regression coefficient is 0.147103 . The probability indicates a value greater than 0.05 or equal to 0.0774 . This means that the greater the significance level of $\alpha=5 \%$, so the hypothesis 1 does not successfully backed up or this study does not reject the H0. This study proves that Perceived Benefit is insignificant on the use of E-Money which is consistent with research conducted by Filona and Misdiyono (2019). Variable Compatibility shows that regression coefficient is 0.138842 . The probability indicates value greater than 0.05 is 0.1850 . This means that the greater the significance level of $\alpha=5 \%$, so the hypothesis 2 do not successfully backed up or this study does not reject the H0. This study proves that compatibility is insignificant on the use of E-Money which is consistent with research conducted by Anjelina (2018).

Variable Perceived Usefulness shows that regression coefficient is 0.355340 . The probability indicates a value less than 0.05 is 0.0002 . This means that the smaller the significance level of $\alpha=5 \%$, so the hypothesis 3 successfully supported or rejected H0. This study proves that Perceived Usefulness of an effect on the use of E-Money. F-test have probability value indicates a value less than 0.05 is 0.0000 . This means that the less than the significance level of $\alpha=5 \%$, so the hypothesis 4 successful supported. This study proves that Perceived of Benefit, Compatibility and of Perceived Usefulness affecrt the use of E-Money simultaneously.

Table 4. Multiple regression result

\begin{tabular}{lcc}
\hline \multicolumn{1}{c}{ Variable } & Coefficients & Probability \\
\hline Constant & 0.849863 & 0.6278 \\
PBN & 0.147103 & 0.0774 \\
CPB & 0.138842 & 0.1850 \\
PUF & 0.355340 & 0.0002 \\
F-Test & 30.84061 & 0.0000 \\
$\mathrm{R}^{2}$ & 0.473205 & \\
\hline Note: PBN is Perceived of Benefit, CPB is Compatibility, and PUF is Perceived Usefulness
\end{tabular}




\section{CONCLUSION}

Based on analysis result and discussion which has been done to this problem using multiple regression analysis. This study proves that Perceived of Benefit and Compatibility as partially do not affect the use of the E-Money significantly. Otherwise, this study proves that Perceived of Usefulness as partially affects the use of E-Money significantly. In addition, this study shows that Perceived of Benefit, Compatibility and Perceived Usefulness affect on the use of E-Money simultaneously.

\section{REFERENCES}

Adityawarman. (2014). Jasa Marga kesulitan siapkan uang kembalian. https://ekbis.sindonews.com/berita/843175/34/jasa-marga-kesulitan-siapkan-uangkembalian

Anjelina. (2018). Persepsikonsumen pada penggunaan e-money. Journal of Applied Managerial Accounting, 2(2), 219-231. https://doi.org/10.30871/jama.v2i2.934

Davis, F. D. (1989). Perceived usefulness, perceived ease of use, and user acceptance of information technology. MIS Quarterly, 13(3), 319-340. https://doi.org/10.2307/249008

Filona \& Misdiyono. (2019). Factors affecting the adoption of electronic money using Technology Acceptance Model and Theory of Planned Behavior. Jurnal Ilmiah Ekonomi Bisnis, 24(1), 108-120. http://dx.doi.org/10.35760/eb.2019.v24i1.1858

Hoffmann, V. (2011). Knowledge and innovation management: Module Reader. https://www.researchgate.net/publication/225616414_Farmers_and_researchers_How can_collaborative_advantages_be created_in_participatory_research_and_technolog y_development

https://www.bi.go.id/id/ruang-media/siaran-pers/Pages/sp_82606.aspx

https://www.bi.go.id/id/sistem-pembayaran/di-indonesia/Contents/Default.aspx

https://www.wartaekonomi.co.id/read210222/menilik-lebih-dalam-kebutuhan-penggunapembayaran-digital-di-indonesia

Lee, M. (2009). Factors influencing the adoption of internet banking: An integration of TAM and TPB with perceived risk and perceived benefit. Electronic Commerce Research and Applications, 8(3), 130-141. https://doi.org/10.1016/j.elerap.2008.11.006

Lintangsari, N., Hidayati, N., Purnamasari, Y., Carolina, H., \& Ramadhan, W. (2018). Analisis pengaruh instrumen pembayaran non-tunai terhadap stabilitas sistem keuangan di Indonesia. Jurnal Dinamika Ekonomi Pembangunan, 1(1), 47-62. https://doi.org/10.14710/jdep.1.1.47-62

Lui, H. \& Jamieson, R. (2003). TriTAM: A model for integrating trust and risk perceptions in business-to-consumer electronics. The $16^{\text {th }}$ Bled Electronic Commerce Conference. https://www.researchgate.net/publication/228918781_TriTAM_A_model_for_integrat ing trust_and_risk_perceptions_in_business-to-consumer_electronics

Ma'ruf, A. (2016). Minat penggunaan produk e-money di kalangan mahasiswaYogyakarta: Analisis faktor pengaruh berdasarkan perspektif TAM dan TPB. Skripsi. Universitas Islam Negeri Sunan Kalijaga. http://digilib.uin-suka.ac.id/24169/

Miliani, L., Purwanegara, M. S., \& Indriani, M. T. D. (2013). Adoption behavior of e-money usage. Information Management and Business Review, 5(7), 369-378. https://doi.org/10.22610/imbr.v5i7.1064

Oliveira, T., Thomas, M., Baptista, G., \& Campos, F. (2016). Mobile payment: Understanding the determinants of customer adoption and intention to recommend the technology. Computers in Human Behavior, 61, 404-414. https://doi.org/10.1016/j.chb.2016.03.030 
Popovska-Kamnar, N. (2014). The use of electronic money and itsimpact on monetary policy. Journal of Contemporary Economic and Business Issues, 1(2), 79-92. https://www.econstor.eu/bitstream/10419/147460/1/86795244X.pdf

Saraswati, N., \& Mukhlis, I. (2018). The influence of debit card, credit card, and e-money transactions toward currency demand in Indonesia. Quantitative Economics Research, 1(2), 87-94. http://journal2.um.ac.id/index.php/qer/article/view/3487

Sekaran, U. (2003). Research methods for business: A skill-building approach, 14th Edition. New York: John Wiley and Sons Inc.

Sugiyono. (2014). Metode penelitian pendidikan pendekatan kuantitatif, kualitatif dan R\&D. Bandung: Alfabeta.

Wulandari, D., Soseco, T., \& Narmaditya, B. S. (2016). Analysis of the use of electronic money in efforts to support the less cash society. International Finance and Banking, 3(1), 1-10. https://doi.org/10.5296/ifb.v3i1.8802

Yulianto, Y., Ferdinand, A., \& Soesanto, H. (2016). Studi mengenai pengaruh tekanan waktu untuk membeli, derajat diferensiasi produk dan customer value terhadap minat bertransaksi ulang menggunakan uang elektronik (Studi pada pengguna uang elektronik e-money di Kota Semarang). Jurnal Sains Pemasaran Indonesia (Indonesian Journal of $\begin{array}{lrr}\text { Marketing } \quad \text { Science), 15(3), } & \text { 152-167. }\end{array}$ https://ejournal.undip.ac.id/index.php/jspi/article/view/14243 